\title{
The Nazi Connection
}

$S^{c}$ everal times in the past few years I have been brought up short by the suggestion that ecological restoration is a form of nativism-the ecological version of the sort of racist policies espoused by the Nazis or the Ku Klux Klan.

Like the Nazis and the Klan, restorationists espouse the exclusion and removal of immigrants, and even a program to ensure genetic purity of stock in order to protect the integrity of the native, the true-born, the Blut und Boden. Hence restoration offers a disturbing resemblance in the ecological sphere to policies of nativism, racism, and sexism in the social sphere-so the argument goes.

I came across this most recently just a few weeks ago, in an article in The New York Times Magazine (May 15, 1994) titled "Against Nativism," in which garden writer Michael Pollan offers a kind of political critique of restoration —or at least the domesticated form of restoration known as natural gardening.

Reacting to criticism of his own garden philosophy, which is unabashedly soft on exotics, Pollan argues that the natural gardening movement that he sees sweeping the United States is nativist and "antihumanist, particularly in the way it seeks to erase people and history from the landscape." He goes on to link the movement with a horticultural program developed under the supervision of Nazi leader Heinrich Himmler during the 1930s.

Pollan, it should be noted, is generally friendly toward restoration. In fact, his 1991 book Second Nature, a thoughtful, literate account of his own gardening experiences, dealt sympathetically with the subject of restoration as an approach to natural area conservation.

Obviously, his is criticism we are going to have to take seriously-especially if we want, as I do, to take restoration itself seriously, not just as an environmental technology, but because of what it means.

So what can we say in response to the charge of eco-nativism?

First, on a purely ecological level, that in many cases a policy of restoration-including measures to exclude, eliminate, or control certain exotic species-is necessary if we are to hang onto classic ecosystems and the plants and animals that make them up. A case in point is the prairies and savannas of the Midwest: their survival at this juncture clearly depends on fire and other restorative measures, a primary objective of which is to controlor, if you will, discriminate against- exotic species.

This may be decried as "nativism," a term loaded with negative connotations and one that evokes some of the ugliest events in history. But is this really fair, when the whole purpose is in fact to protect the oppressed and threatened group from extinction? Is it fair, or even accurate, to compare this with the Holocaust? In fact, to stick to parallels drawn from the World War II era, isn't it more like the creation of modern Israel to allow for the survival of something of value?

This certainly entailed sacrifices, and even ethical compromises. Yet few would suggest that it was unambiguously evil in intent or in implementation, as was the Nazi program.

Then too, consider the alternatives. What Pollan idealizesa garden in which natives mix happily with a selection of the less troublesome exotics-is fine with me. Yet if strict restoration reminds some of fascism, it would seem that this looks like the ecological version of the social melting pot-a notion of cultural relations that has long been in disrepute and that in fact many now regard as racist.

Actually, it seems to me, the melting pot is one extreme, nativism the other. What we want, as usual, is in between - that is, different kinds of communities (prairie and vegetable garden, Anglo and Hispanic, and so on) that retain a measure of identity. And we want relationships between them.

Negotiating those relationships takes work-intellectual, psychological, and spiritual work. And in the area of the environment one term for that work is ecological restoration.

Pollan objects to native gardening because it entails discriminating between native and exotic. But it's well to keep in mind that there is no honorable way to avoid discrimination, and that the opposite of discriminating is indiscriminate. Indeed, once you start throwing out discrimination you wind up throwing out just about everything - agriculture, certainly, and, it turns out, community as well.

What we need is not an end to discrimination, but an exquisitely sensitive ethic of discrimination, based on insight, respect, and love. 
And this will certainly include programs of restoration, including strict restoration, at least in some areas.

Pollan also finds the native garden to be anti-human. But it seems to me that this is because he is looking only at the garden itself, and is overlooking the gardener toiling in the foreground. Once he takes the gardener and his or her experience into account I suspect he will come to see native gardening as just what he is looking for-that is, not a way of excluding people from the garden, but a way of including them in the natural landscape.
Actually, reading Pollan's essay with some care, and keeping in mind the sensible, balanced discussion of restoration in his book, I have a feeling that he would agree with this.

I suspect it's not so much restoration and the natural garden he objects to as the tone of voice in which these matters are sometimes discussed.

That, too, is worth keeping in mind.

William R. Jordan III 